\title{
In the Shadow of the Monster: Gothic Narratives of Violence Prevention
}

\author{
Sara Skott $^{1}$ (D) . Sara Nyhlén ${ }^{1} \cdot$ Katarina Giritli-Nygren $^{1}$
}

Published online: 14 September 2020

(c) The Author(s) 2020

\begin{abstract}
This article examines narratives by professionals working on preventing gender-based violence in Sweden through a Gothic lens. It draws on interviews with authorities responsible for preventing gender-based violence in one region of Sweden and explores the way national policies are translated into regional action. Our analysis shows how the "reel" is adopted by the professionals and becomes a part of the "real," resulting in implications for policy. By looking at the participants' narratives through a Gothic lens, this article argues that local-level professionals working to prevent violence frame gender-based violence as a problem of two "othered" groups: the "Immigrant Other" and the "Rural Other." Through a narratological strategy of illumination and obscurity, these groups of offenders are rendered both uncanny and monstrous by the respondents - a monstrosity that obscures any violence occurring outside this framing. The problem of gender-based violence is relegated from the site of the mundane to the sphere of the monstrous.
\end{abstract}

\section{Introduction}

... just as Little Red Riding Hood entered the wood, a wolf met her. Red Riding Hood did not know what a wicked creature he was, and was not at all afraid of him. (Brothers Grimm 1812: 51)

In this study, we use a Gothic lens to explore narratives of professionals working to prevent gender-based violence among youth. While previous studies have examined the narratives of people engaging in violence (see, e.g., Brookman et al. 2011; Fleetwood 2016; Sandberg et al. 2015), fewer studies have considered the narratives of victims of violence (for exceptions, see, e.g., Cook and Walklate 2019; Hourigan 2019; Ievins 2019; Pemberton et al.

Sara Skott

sara.skott@miun.se

Sara Nyhlén

sara.nyhlen@miun.se

Katarina Giritli-Nygren

Katarina.Giritli-Nygren@miun.se

1 Department of Humanities and Social Sciences, Mid Sweden University, Holmgatan 10, 85170 Sundsvall, Sweden 
2018; Rogers 2019; Walklate et al. 2019), and fewer still have explored the narratives of violence constructed by those working to prevent violence. This has led to a fundamental lack of understanding of how violence is constructed, storied, and perceived among the authorities tasked with preventing it.

So, why a Gothic lens? Contemporary society has been permeated by the Gothic. As Sothcott (2016: 432) suggests, the "Late Modern Gothic not only refers to fanciful creations, artistic endeavors or fashionable apparel, it is also a mode by which transgressive behavior is 'storied', rendered into discourse and hence both directly and indirectly experienced as real and not merely improbable possibilities." In reality, crime victims and offenders do not always fit with our conception about the "perfect victim" or "perfect offender," as seen in "reel" worlds (Picart and Greek 2007). Such portrayals are clearly visible in newspapers and television shows, and are strikingly similar to the story of Little Red Riding Hood, quoted in the epigraph above. In such mediated realities, a woman who is the "perfect crime victim" is a woman who is morally unquestionable, completely innocent, and lives an ordinary life (Christie 1986). The "perfect offender" is an unfamiliar, uncivilized, and exceptional man. Much imagery of "reel" crime can thus be boiled down to stories of the innocent little girl and the lone, monstrous wolf.

While this intersection of the "real" and the "reel" and its effects on public policy relating to crime and justice has been the focus of recent academic interest pertaining to the Gothic (Picart and Greek 2007), the idea of the unfamiliar and uncivilized man as the "perfect offender" can be traced back to Lombroso and his notion of the atavistic other. The Gothicity of Lombroso's ideas "turned the criminal into a creature utterly different from normal man: a vampire, an atavism, a degenerate, closer to apes and savages and rodents than to law-abiding citizens" (Rafter and Ystehede 2010: 282). Lombroso's vast influence on punishment and social control continues, as demonstrated by the possible impact that Gothic narratives of offending may have on public policy. A victim who does not correspond to the innocence of Little Red Riding Hood does not receive the unqualified status of "victim." Instead, the woman, herself, may be suspected of causing her own crime by dressing inappropriately, by being in the wrong place, or by behaving inappropriately. If the offender does not correspond to the unfamiliar, uncivilized, and exceptional "wolf," he might pass unnoticed, as, for example, in the case of the "Haga Man"-a caring (ethnically Swedish) dad with a solid career who raped several women in a Swedish town, but who did not match the image of the wolf or the "perfect offender" and was thereby very difficult to detect (Livholts 2007).

This article is based on interviews with administrative and school personnel in charge of coordinating the implementation of national strategies to combat gender-based violence at the regional and local levels. In analyzing this material, we found that these individuals' narratives pointed to gender-based violence as a specific "new" form of violence-one attached to certain groups of men (Nyhlén and Giritli Nygren 2019). Because this work is a part of a larger project in which we have also been using visual methodologies to explore high school girls' perceptions of growing up in rural places, especially in connection with violence (Brännström et al. 2019), we were surprised by the narratives of the persons working on preventing gender-based violence. The girls portrayed a picture of different forms of gender-based violence, where sexual harassment is a common and a constant risk; the offenders could be "anyone"-boys, fathers or even other girls, without any particular references to class, ethnicity or race-and the violence could happen online or offline, at school or somewhere else (Brännström et al. 2019). The personnel working on prevention, however, offered a significantly different picture, attaching gender-based violence to "certain groups" based on ethnicity and "culture" regarding both offenders and the girls "at 
risk" (Nyhlén and Giritli Nygren 2019). They also made clear references to popular cultural ideas about men, rural life, violence, and violent places, contributing to the construction of "wolves" as offenders, which, we argue, impacts the enactment of violence-prevention policies. The focus of this study is, therefore, to examine how gender-based violence is storied by Swedish authorities working on this issue on a regional and local level by exploring the Gothicity of their narratives concerning gender-based violence. We undertake this examination in order to trace how the narratives are informed by contemporary Gothic notions about violence, where the violence occurs, and who the offender is or might be. In this way, a Gothic lens enables us to explore the process of othering both in the real world and in its connections to the reel.

\section{The Gothic Lens}

"Oh! Grandmother," she said, "what big ears you have!"

"All the better to hear you with, my child," was the reply.

"But, grandmother, what big eyes you have!" she said.

"All the better to see you with, my dear."

"But, grandmother, what large hands you have!"

"All the better to hug you with."

"Oh! But, grandmother, what a terrible big mouth you have!"

"All the better to eat you with!" (Brothers Grimm 1812: 52)

As a literary concept, the "Gothic" defies consistent definitions, constantly revaluating and reinventing itself (McEvoy 2007; Picart and Greek 2007). Dating back to works, such as Horace Walpole's The Castle of Otranto ([1764] 2014) and Mary Shelley's Frankenstein ([1818] 2013), the Gothic emerged as a reaction to the Enlightenment ideals of order, rationality, and rules. The Gothic imagination deals with extreme contrasts, the erosion of boundaries, and an emphasis on ambivalence and uncertainty that contribute to an infinite spectrum of the "real" and imagined. Illumination and obscurity are two recurrent themes in Gothicism, which not only create an atmosphere of contrasts, but simultaneously hide and reveal (Fernandez et al. 2013; Niedenthal 2009). What is steeped in darkness is uncertain, indistinct, and out of focus; it is hidden from sight (and mind) and this darkness prohibits our clear perception. As Niedenthal (2009: 6) argues, "the opposite of obscurity is not light, but clarity." Illumination and obscurity have, therefore, been used as strategies to create a narrative in Gothic contexts. The Gothic furthermore thrives in the liminal because it broadens the scope of consciousness and blurs normative structures. Gothicism, therefore, often concerns itself with decay, disease, and death, as symbolic revolts against "sexual, political and religious taboos" (Picart and Greek 2007: 24).

While predating Gothic literature (Spooner and McEvoy 2007), folkloric tales have been identified as a significant source for Gothic tropes and themes (Markey 2014). Both genres share an "association with superstition, transgression of rationality, [and] fascination with the supernatural" (Markey 2014: 94), and the coining of the term, "folklore," in the nineteenth century has served to blend the two genres together. While folkloric tales evoke Gothic themes, the Gothic also often incorporates folklore, using its familiarity and myth to induce magic and terror (Botting 1996; Haslam 2007). This symbiotic relationship further highlights the Gothicity of folkloric narratives. As an example of this, the tale of Little Red Riding Hood is riddled with Gothic narratives, exemplified by the monstrous and the abject (in the shape of the wolf) and the uncanny doubling of the wolf-qua-grandmother. 
Previous studies have shown how the wolf in the story functions as a metaphor for sex and rape and how the story contains themes of predator avoidance, as well as the popular idea that "strangers can be dangerous" (Kohm and Greenhill 2013: 367). The erosion of boundaries between beast and human, monster and mortal, evident in the story further serves to blur normative structures and to promote obscurity. The wolf is liminal, in-between, and must be cast out for order to be restored. Due to the Gothicity of this story, Little Red Riding Hood will be used as a framing device throughout this article in order to highlight the "reel" Gothic logic of our findings. The following parts will provide background for the theoretical framework used in the current article, outlining the area of Gothic Criminology, as well as concepts relevant for our analysis.

\section{Gothic Criminology}

While perhaps some of the most notable Gothic works were published before the twentieth century, the Gothic still permeates our contemporary cultural imagination, prevalent in numerous forms of media, ranging from literary works to graphic novels, theater, and video games (Picart and Greek 2007; Spooner 2007). The Gothic has also found its way into academic studies outside the realm of literature and media, such as criminology. Owing its lineage to cultural criminology, as well as to Gothic literature and film theory (Picart and Greek 2007: 13), Gothic criminology draws on cultural criminology, feminist criminology, power-control theory, and Foucauldian perspectives (Picart and Greek 2007: 16). Gothic criminology endeavors to examine "the other" and the societal construction of the monstrous in both "real" and "reel" worlds (see, e.g., Fredriksson 2019). Gothic criminology has also explored the relevance of the Gothic to popular criminology and criminal policies (Rafter and Ystehede 2010), as well as its connection to green criminology (South 2017). By examining the public imaginary surrounding crime, criminality, and justice, Gothic criminology considers the way that mediated and aesthetic accounts of deviance intersect with public policy in complex ways. As previous studies have shown (see, e.g., Rafter and Ystehede 2010), Gothic narratives may have a significant impact on the development of public policy. Much like Spooner (2007: 8) has suggested, the spread of the Gothic has not been restricted to shaping media reports of sensationalist crime; rather, Gothic narratives have also been constructing the perception of criminal transgression and justice, more generally. According to Valier (2002: 321), punitive populism is built on Gothic tropes, which are "embedded in the practices of the institutions of crime control and punishment themselves." Sensationalist crimes are no longer considered anomalies, but permanent insidious features with repetitive themes of haunting and dereliction, from which, in true Gothic spirit, there is no rescue or escape (Valier 2002: 323). The populism of today does not simply come from mass-mediated stories, but instead reflects cultural anxieties and a longing for categorical certainties in the vertiginous conditions of late modernity (Sothcott 2016; Valier 2002; Young 2007). The Gothic imagination is, therefore, not only a projection of anxiety striving to reinforce cultural boundaries, but is also used to actively disrupt these boundaries, "exposing their cultural fragility" (Sothcott 2016: 436). The more porous the boundaries between public and private, information and entertainment, legal and extralegal become, the more influence Gothic narratives will have on criminal justice policies (Valier 2002). As such, Gothicity not only molds our perception of offenders and offending, but also permeates punishment and the criminal justice processes. 
By using a theoretical stance informed by Gothic criminology, our study endeavors to examine how the cultural imaginary of gender-based violence is informed by Gothic narratives among professionals working to prevent such violence and how these understandings affect the preventative strategies proposed by the professionals. As such, our study contemplates how the "real" narratives of professionals working to prevent gender-based violence are informed by "reel" Gothic narratives of offenders and offending. Central to such an analysis are also the concepts of "the uncanny" and "the abject," which we explore in the next part.

\section{The Uncanny and the Abject}

The concepts of the uncanny and the abject are two Gothic themes often utilized as tools in Gothic criminological analysis. The uncanny, originally developed by Freud (1919/2001), has been understood as "the familiar, unfamiliarized" (Hurley 2007: 141). While also defined as "unhomely," due to Freud's original term unheimlich, the uncanny alludes to sites or places that were once familiar (Freud 1919/2001; Spittle 2011). As a complex analytical framework with multiple meanings, the uncanny concerns itself with doubling, the blurring of boundaries (such as between life and death or self and other), and the repression of that which threatens those boundaries, particularly the sense of self (Fiddler 2013; Fredriksson 2019). The uncanny is the unknowable that separates and yet, paradoxically, unsettles boundaries, which often causes a haunting sense of anxiety. As Fiddler (2013) suggests, the uncanny figure of late modernity, symbolic of our ontological anxieties, is characterized by its alien and estranged character.

"Abjection" is closely related to the concept of the uncanny (Spittle 2011). Defining the "abject" as "familiar but unfamiliar, in short, too close to the borders of our subjectivity for comfort," Spittle (2011: 315) places the abject in the realm of the uncanny. The abject was originally defined by Kristeva (1982: 4) as that which "disturbs identity, system, order. What does not respect borders, positions, rules. The in-between, the ambiguous, the composite." By disrespecting and dissolving borders, the abject threatens our identity (national or otherwise) and our sense of self. Only by removing the abject can these borders be maintained and identity be protected (Kristeva 1982).

Kristeva (1982) developed the idea of abjection as the othering of female identities, taking gendered power orders into account. By repressing and othering that which is feminine, abjection can be seen as an expression of gendered power hierarchies-a practice that is also identity-forming. Thus, the abject has been defined as "that which breaches borders" (Valier 2002: 321) and involves the unsettling of borders and perceived boundaries between self and other, subject and object. While the uncanny disrupts, disturbs, or unsettles boundaries, that which is abject needs to be removed in order to maintain these boundaries.

While the uncanny and the abject are closely related, they are also linked to the figure of the monster. As Beal (2002: 6) argued, the monster can be read as a personification of the uncanny- "of otherness within sameness"-illustrated by the quotation above where the wolf appears in the familiar bed of the grandmother, but strange because of his unfamiliar monstrous look. The monster, in the Gothic imagination, is representative of social traumas, for which it is also blamed (Ingebretsen 2001). Monsters define the boundaries of normal and other: "By locating monsters off the social map, we are locating ourselves on it" (Ingebretsen 2001: 5). 
...when Red Riding Hood was again taking cakes to the old grandmother, another wolf spoke to her, and tried to entice her from the path. Red Riding Hood, however, was on her guard, and went straight forward on her way, and told her grandmother that she had met the wolf, and that he had said "good morning" to her, but with such a wicked look in his eyes, that if they had not been on the public road she was certain he would have eaten her up. (Brothers Grimm 1812: 53)

The monster is thus a paradox: on the one hand, representative of the behaviors that threaten society and, on the other, that which makes such incivilities possible, even justifying such behavior in the name of the common good. Monsters are agents of moralized fear, to which social cruelty is normalized in the name of "the civil" (Ingebretsen 2001: 3). Because the monster must also be destroyed, it cannot be allowed to live if society is to purge itself of whatever social ill it represents. As Ingebretsen (2001: 2) argues, "the violence condoned in such ceremonies is overlooked in the leering spectacle of their display." What makes the monster different from other forms of othering is thus that it needs to be annihilated, and that such annihilation is legitimized and condoned. The construction of the monstrous offender, building on the Gothic idea of the predatory criminal, whereby offenders are portrayed as "animalistic, incorrigible and innately evil" (Surette 2007: 205), has been popularized recently through the portrayals of offenders in the media landscape. DiBennardo (2018) discusses how news media research has focused mainly on the framing of victims without examining how these framings may also shape representations of offenders. Such framing seems to highlight the dangers of violent crime by strangers (Greer 2003; Lancaster 2011) and can be part of the implicit constructions of community togetherness (Jewkes 2015) and otherness, such as implicit racism (Nagel 2003). When it comes to sex offenders, in particular, this framing tends to perpetuate the idea that those who commit sex crimes have unique, unknown, and monstrous identities (Greer 2012; Leon 2011). Such images of the offender are contrasted with the idea of "normal" human citizens, which further highlights their difference and monstrosity. They are predators, hunters, and, therefore, irredeemable creatures who cannot be domesticated or rehabilitated.

Monsters, however, are also transgressive: often the victims of circumstance, they cross boundaries and categorical distinctions, which both fascinates and frightens us (Ingebretsen 2001; Sothcott 2016). At the same time, monsters serve to redefine frayed boundaries, as well as to warn the public - in a process that helps society reinterpret itself. The monster is also often denied a voice, which is symbolic of its alienation; if the monster does speak, it is often in the voice of its master (Ingebretsen 2001: 11). Gothic narratives of violence can, therefore, be seen as politically useful tools to legitimize the intensification of social control mechanisms and to increase state control. The Gothicity of violence, specifically the construction of monstrosity, has been found to be an important feature of the exercise of colonial power (Higgins and Swartz 2018). The state or colonizers, then, themselves, engage in monstrous responses, which are justified and made invisible by the threat entailed by the constructed monster. As a type of normalization technique (Sykes and Matza 1957), this "allow(s) the colonizer to label the monstrosity of the Other as deviant and neutralize their monstrosity as a reflection of one's own state violence" (Higgins and Swartz 2018: 94). Gothic narratives of marginalized groups furthermore play an important part in the practice of defending modern borders, where state violence is viewed as a moral and justified response against degeneration. There is consequently a link between the uncanny, the abject, and the monster because the monster can be seen as a personification of both. As such, this article will argue that the combination of the uncanny (that which is other, yet the 
same) with the abject (that which must be removed in order to protect borders) can create something monstrous in the context of violence prevention policy.

\section{Methodological Considerations in Narrating Monstrosity}

In order to examine how gender-based violence is "storied" (Sothcott 2016: 432), this study takes a narratological approach, exploring the Gothic narratives symbolic of underlying cultural anxieties. As Sandberg and colleagues (2015: 3) contend, narratives move beyond simple storytelling, not only by shaping collective conscience, but by positioning actors and events in plots, as well as by allocating moral responsibility and agency. The increased use of narrative methodology within criminology and sociology can be related to the post-structuralist emphasis on ambiguity, complexity, and interpretive openness (Sandberg et al. 2015), allowing for intertextuality and multiple meanings of narratives (Derrida 1978; Frank 2010). This makes narrative analysis particularly suitable for studying stories of violence (e.g., Brookman et al. 2011; Fleetwood 2016; Sandberg et al. 2015). While narratives of violence previously have been considered stories of neutralization (Maruna and Copes 2005; Sykes and Matza 1957), narratives of violence also "report, educate, transmit meaning, create order, construct identity, uphold culture, integrate and deal with experiences, explore taboos and entertain both storyteller and audiences" (Sandberg et al. 2015: 5).

Gender-based violence in Sweden is regulated at a national level, but the municipalities, themselves, decide how the task is to be performed (Erlingsson and Wänström 2015). The different local authorities receive assignments from the government over the course of a year, which determine their work and roles in policy-making and implementation (SOU 2015: 55). This includes preventive policy work to address men's violence against women, as well as "honor-based" violence and oppression (violence and control perpetrated in families in order to protect perceived cultural and religious beliefs and/or honor).

Our study took place in a region that is geographically large (approximately $21,700 \mathrm{~km}^{2}$ ) and consists of seven municipalities. The municipality chosen for this study is the most rural of them. The region is located in the northern part of Sweden, which means that it is a sparsely-populated area. The distances between towns and homes are considerable, and the municipality lacks many support organizations, such as women's shelters and youth counseling clinics. The municipality contains only one high school, which is included in this study. The County Administrative Board is located in the center of the region and is in charge of coordinating the preventive work in the seven municipalities.

The material analyzed in this article is based on three group interviews and one singleperson interview with a total of nine informants ${ }^{1}$ who were selected because they work at different levels of policy-making in the field. While this is a small sample, it reflects all the levels of people responsible for preventing gender-based violence in the region and in the municipality, providing a nuanced understanding of the policy-making process: politicians, school personnel, and administrative workers from the municipality as well as from the

\footnotetext{
${ }^{1}$ The respondents were guaranteed confidentiality and we made it clear that the research sites, i.e., the county, municipality and school, would be presented in such a way that it would be difficult to identify any participant.
} 
County Administrative Board. ${ }^{2}$ Group 1 consisted of two officials on the County Administrative Board. Group 2 consisted of municipality personnel: one was the head of the administrative services, which includes the responsibility for public health in the municipality; one was a politician and the Municipal Chief Executive; and the third was the head of security in the municipality. The single-informant interview was with the high school principal. We also interviewed the student health team (Group 3), which consisted of a school nurse, a school counselor, and a guidance counselor.

The interviews sought to explore the everyday practices in the field of gender-based violence. They lasted between sixty- and ninety-minutes and were recorded and transcribed verbatim. In the interviews, we asked questions about the regulatory frameworks governing the preventive work and how the actors worked in the field on an everyday basis. The informants were positioned as the "knowers," which meant that they were given opportunities to talk openly about their work, instead of just offering responses to our questions. This meant that the informants could describe their work in their own words and that the interviews included lengthy discussions about what gender-based violence "really is," including constructions of the violence, the victims, the offenders, and how to prevent it. The group approach enabled an in-depth discussion about the everyday work from different institutional and professional settings, which increased the complexity of the narratives, although the group context did present the challenge of ensuring that everyone had a chance to share his/her perspective. The methodological approach was chosen due to its capacity to be flexible and allow the collection of rich data.

After conducting the interviews, we examined the narratives of the professionals to identify key recurring themes associated with gender-based violence. Similar to previous studies in Gothic criminology (e.g., Fredriksson 2019), these themes were identified in the interview transcripts after repeated close readings, focusing on how gender-based violence was storied through Gothic imagery. In particular, we examined how both the offenders of gender-based violence and the violence, itself, was rendered abject and uncanny, as well as monstrous.

\section{The Uncanny and the Abject in Narratives of Gender-Based Violence Prevention}

The huntsman was just passing the house, and thought to himself: "How the old woman is snoring! I must just see if she wants anything." So he went into the room, and when he came to the bed, he saw that the wolf was lying in it. "Do I find you here, you old sinner!" said he. "I have long sought you!" (Brothers Grimm 1812: 52)

Similar to the huntsman in the quotation above, who found the offender he had sought for so long, the interviewees in our study also indicated that they felt they had identified the perpetrators of gender-based violence and the causes for their actions. The Gothic narratives around the prevention of gender-based violence constructed by the respondents consistently included references to or reflections of illumination and obscurity, visibility, and invisibility (Fernandez et al. 2013; Niedenthal 2009). The respondents, themselves, admitted that they were creating a narrative around violence in order to engage stakeholders and

\footnotetext{
2 The County Administrative Boards conduct work on the regional level and are responsible for ensuring that the directives from the government are implemented through local action plans in the municipalities.
} 
to promote change: "We are lobbyists through and through [...] I know what I have to say. Or I'm trying to figure out, "what do I have to say in this situation in order to get what I want?' (Respondent 2, Group Interview 1).

In this way—and as argued by Sandberg and colleagues (2015) — the narratives moved beyond storytelling to shape a collective conscience. The respondents positioned themselves as active agents and, in considering themselves "lobbyists," they claimed agency and moral responsibility. They saw their duty as that of warning the public-part of the process of helping society reinterpret itself. In this case, we argue that it is the rural aspects that becomes illuminated and visible, constructed, as Linnemann (2016) argues, as an important part of the our social imagination in relation to the rural. This imagination, as a technology of power, provides the possibilities for the production of ideas of the uncanny and violence in relation to rurality (see McClanahan and Linnemann 2018). In this way, the social imaginary "haunts" the social space, informing and contributing to everyday understandings of, in this case, rurality (Linnemann 2015). By actively creating a story about violence, the respondents were illuminating certain narratives around gender-based violence, emphasizing certain groups of offenders, and making them (more) visible. Two groups emerged from their narratives and, through their othering, were constructed as the main offenders of gender-based violence: the "Rural Other" and its uncanny double, the "Immigrant Other."

\section{The Rural Other}

A narrative of the Rural Other emerged in the interviews and became a key character in the story of gender-based violence prevention. The Rural Other was constructed as being firmly rooted in rurality, which was also the very cause of the othering. Notions of tightknit communities, strong social control, and ignorance of what violence actually is were all tied to the construction of the Rural Other and storied as a part of their rural identity. One important aspect is that several of the professionals working on preventing violence did not, themselves, live or work in rural areas, but in the regional capital. As a result, the professionals based in the regional capital would often conceive of the Rural Other as deviant, which neutralized the professionals' own potential rurality (cf. Sykes and Matza 1957). McClanahan and Linnemann (2018) argue that there is a dialectical relationship to rurality: it is both idyllic and anti-idyllic, as well as known and unknown, which creates a social geography of violence at the edges of invisibility. The professionals' stories about rurality display the socio-cartographic power of the state and capital (McClanahan and Linnemann 2018) and the cognitive process of strategic ignorance and denial (see McGoey 2012), which are informed by the images of immigrants, masculinity, power, rurality, and violence that we encounter in our everyday lives. One example of this is the professionals' conception that crimes in rural locations are more serious or violent than those in urban environments:

Women in rural communities are more exposed to violence. ... Unfortunately, this does not come to the knowledge of the authorities. There is another social control as well. [Respondent 1, Group Interview 1]

Yes ..., there is another type of social control which often makes the violence... rougher and help is further away, and the thresholds are higher and all of that. So the 
victimization is actually worse in rural communities. [Respondent 2, Group Interview 1]

This emphasis on the vulnerability of rural victims, mostly women, creates a narrative of rural communities as not only different, but as more dangerous. This dangerousness is further understood as a failure on the part of rural communities to recognize the gender-based violence as violence, thereby constructing the Rural Other as ignorant. Not only does the Rural Other not share the authorities' (urban) understanding of violence, but the social dynamics in rural communities functions to mask (the) violence-to obscure it and hide it from plain sight: "We sometimes have to declare how dangerous the violence is and how it affects, and what it may cost, and even who may be affected by it" (Respondent 2, Group Interview 1).

All of these factors served to construct gender-based violence in rural communities as different, more dangerous, and more prevalent in comparison to other (urban) contexts. This, in turn, prompted the local authority workers to feel obliged to elucidate this violence, bringing it to the forefront when framing the problem of violence, in line with their "storying" of the violence.

\section{The Immigrant Other}

The Rural Other has an uncanny double - the Immigrant Other. All of our respondents constructed the issue of gender-based violence as a problem relating to honor-related violence by immigrants:

Honor-related stuff, both violence and other things. We have fights between different beliefs, if you're simplifying it. We are dealing with the risk of being married off against your will. Of being circumcised, I mean, by force. In general we are dealing with equality issues and all of that, you know. [Respondent 2, Group Interview 3]

I know we have had and that we have honor-related problems at the school. [Single interview with the high school principal]

It's more focused on the honor-related problems. You do have that perspective. [Respondent 2, Group Interview 1]

Gender-based violence was described as a problem peculiar to rural locations or equated with honor-related violence-and something that the interviewees, as professionals, had been trained to identify. In this way, the professionals resembled the Huntsman-the ones able to detect the monster.

The offenders were referred to as alien, ignorant, and incomprehensible. Not only were these Immigrant Others depicted as displaying a lack of understanding of the Swedish system in which they lived, but the victims of this violence were also portrayed as ignorant of their own victimization and oblivious to their rights: "And sometimes it's like, that when they get here they couldn't speak Swedish. Didn't know their rights, they didn't know what the Swedish system looked like" (Respondent 2, Group Interview 1).

Immigrants were described as being subjected to outside and sometimes even international control by their families: "it could be control from their homeland too. Or where the family is. It could just as well be in Gothenburg as in Germany, or that they're still in Iran" (Respondent 2, Group Interview 3). These narratives framed the offenders and victims as different - as Immigrant Others_-who were not only in conflict with egalitarian (Swedish) values, but who were also rendered victims of their own circumstances (their cultures). 
The narratives of gender-based violence constructed the violence as committed mainly by the Rural Other and the Immigrant Other, which not only othered the offenders, but also rendered this familiar violence unfamiliar-as something new, for which they did not have any ready solutions: "Honor-related things, both violence and other things. ... [T]he[re] are new things to which it isn't super easy to invent solutions for" (Respondent 2, Group Interview 1).

The participants' positioning of the Immigrant Other as lacking understanding and incapable of integration into society, coupled with the control forced upon them by their families, rendered the Immigrant Others liminal—in between worlds:

You can't just magically remove the problems and just hand over the knowledge to the kids. Because they live in families, many of them, and... if they haven't got a residence permit, ... they haven't received any information about society ..., [which makes it difficult] to be integrated. [...] They are torn between two worlds, almost. [Respondent 2, Group Interview 3]

By emphasizing the liminality of the Immigrant Others, the respondents also enforced the Immigrant Others' otherness: they do not belong; they are unknown, unfamiliar, and uncannily rootless. It is precisely this rootlessness which was constructed as the cause of their violence: they are violent because they are rootless, but also rootless (and Other) because they are violent.

\section{Gender-Based Violence as Monstrous or Mundane}

Gender-based violence, which is neither new nor unfamiliar in Sweden (Brännström et al. 2019; Nyhlén and Giritli Nygren 2019), was reframed in this narrative as alien and strange-just like the offenders committing it. The violence to which the professionals directed their prevention efforts were rendered uncanny by the informants-as something unfamiliar and different. As the analysis above demonstrates, the problem of gender-based violence was not framed as a ubiquitous problem, but as one caused by two othered groups. The otherness of these two groups was emphasized consistently by our informants in their claims that the Rural Other and Immigrant Other were ignorant about or oblivious to urban and Swedish values. While the othering stemmed from their rootlessness, in the case of the Immigrant Other, and their rootedness in the case of the Rural Other, they were both defined by their otherness, their liminality, and their unfamiliarity in the eyes of the professionals.

While this process of rendering unfamiliar familiar violence serves to demarcate and illuminate the boundaries between the violent offender of gender-based violence and the law-abiding citizen, the very act of rendering the familiar unfamiliar destabilizes these boundaries. The Immigrant Other and Rural Other, therefore, also threaten to become abject within the context of these narratives- "as that which breaches borders" (Valier 2002: 321). It is precisely this threat of the Immigrant Others and Rural Others "disturb[ing] identity, system and order" (Kristeva 1982: 4) - the threat of the uncanny becoming abject—which forces this distinct demarcation of the Other in the respondents' narratives. This demarcation, or illumination, is comparable to the monstrous because, much like the monster, the Immigrant Other and Rural Other illuminate boundaries, rendering them visible and thereby serving as luminous warnings (Ingebretsen 2001). Not only are these uncanny Others constructed by the participants in order to redefine the boundaries around gender-based violence and to reinterpret the problem as that of a few 
rather than of many, but the Immigrant Other and Rural Other are also rendered voiceless through their Swedish or urban illiteracy. Like the monster, both the Immigrant Other and the Rural Other become or are treated as victims of their cultural circumstance-effectively without agency. Even their violence is described in uncanny, monstrous terms, causing a haunting sense of anxiety: "But the violence also frightens, $\ldots$ it is unsettling. It crawls in underneath your skin" (Respondent 2, Group Interview 1).

This active storying of these two uncanny and monstrous Others into focal points for the problem of gender-based violence through a strategy of illumination was a response to its perceived invisibility or obscurity by the respondents:

And this issue is taboo, it doesn't show on the outside in the same way as maybe a... if you're talking about social problems, substance abuse is more visible at times. Yes, and it is easier to deal with, I think. [Respondent 2, Group Interview 1]

But we see that when we ask for statistics [of violence in rural communities] for instance, we see that ... the numbers are low when it comes to intimate partner violence. And ... we don't really believe that. We think that there is a lot more violence happening that they don't know of. And why don't they see this violence? [Respondent 1, Group Interview 1]

If we take the asylum-seeking pupils, for instance. This has been such an infected issue in the whole country, so we haven't been allowed to discuss certain things. And when we finally were permitted to discuss, the problems were already there. ... When the politicians accept and have the courage to remove the blindfolds and see, and understand that "yes, this exists even with us," then you can begin to intervene.

[Respondent 2, Group Interview 3]

By shining a light on the problematic Others, the respondents dragged them from the shadows - from obscurity to light — and made them visible. The respondents found the monstrous wolf and were finally allowed to talk about him. Essentially, making the Immigrant Other and Rural Other into focal points effectively rendered gender-based violence by any other type of offender, particularly the urban Swedish male, invisible. Such violence was never acknowledged by any of the respondents, making it remarkable in its absence. By rendering the violence by urban Swedish males obscure, the respondents are also making it unknowable, indistinct and out of focus - spectrally hidden, haunting the margins of their narratives, yet never fully entering them. This spectral obscurity stands in sharp contrast to the monstrous luminescence of the monstrous Others, and it relegates gender-based violence to the sphere of the monstrous - to the site of the fantastic, which effectively removes it from the ordinary, normal and mundane.

By constructing a monstrous narrative around the Immigrant Other and Rural Other, the respondents were locating the violence of these Othered offenders outside the responsibility of society, declaring the problems personal or even biological (Surette 2007), and the respondents were thereby effectively de-responsibilizing themselves of the violence committed by the offenders. As monsters, their violence was relegated beyond the control and influence of society. Gender-based violence became not a mundane problem of ordinary (Swedish urban) men, but a monstrous problem of Immigrant Others and Rural Others, and thus partly beyond the scope of prevention. 


\section{Discussion: In the Shadow of the Monster}

"Well," said the grandmother, "we will shut the door, so that he can not come in." [Brothers Grimm 1812: 53].

This article has considered how violence is constructed, perceived, and storied among the authorities tasked with preventing such violence. Examining the narratives of local-level authorities working to prevent violence in the northern part of Sweden, this article has argued that the respondents' descriptions and narratives of offenders and gender-based violence contain Gothic logic and themes.

Through the construction of the "ideal offender" - and similar to the Gothic narrative of Little Red Riding Hood - the participants depicted gender-based violence as the actions of "Immigrant Others" and "Rural Others." In this way, gender-based violence became limited to certain groups, constructing an "inside" and an "outside" view of the problem, as demonstrated by the quotation at the beginning of this part. In other words, as long as we remain inside, we are safe from the monsters outside. By illuminating the othered violence in this way, the (familiar) violence became not just unfamiliar and uncanny, but also monstrous.

Representative of our social traumas, the monster illuminates boundaries, serving as a warning and becoming the focal point of the story of gender-based violence. Through the use of this narratological strategy, gender-based violence becomes a problem of a few monstrous others, which serves to legitimize the need to annihilate it (Ingebretsen 2001). As a personification of both the uncanny and the abject, the monster, which breaches the boundaries it illuminates, must be terminated if identity and order are to be protected. Because if these boundaries are dissolved - if the monstrous creeps into the mundane- the Self and the Other become unsustainable categories and we, ourselves, become the monsters. We therefore need to close our doors, lest the wolf step into our homes.

This construction of "ideal offenders," evident in the narratives, is influenced by "reel" perceptions of who offenders are and who they are not. Such constructions of rurality, men, and violence, evident in popular culture through certain films and television shows, contribute to the othering of gender-based violence, demonstrating how the "reel" may affect the "real." This also highlights the importance of studying aesthetic as well as academic accounts of deviance, as well as the effect this intersection has on policy and public imaginary. Paradoxically, although actively using the strategy of storying violence to illuminate the violence the respondents, themselves, see as important, and which has been made obscure by other authorities, the respondents are, themselves, obscuring offenders of violence. Thus, in the position of local-level authorities, they are creating a narrative around gender-based violence that renders certain types of violence invisible. This strategy can therefore also be regarded as another form of abjection, as Kristeva (1982) has conceived of it. In the same way that Kristeva (1982) defined abjection as the othering of feminine identities, where it functions as an expression of a gendered power hierarchy, abjection can be read, here, as the othering of rural or immigrant identities and as an expression of white or urban power orders. Since the abject also threatens our identity, national as well as personal, and must be ejected in order for both borders and identities to be protected (Kristeva 1982), narratives such as the ones evident by the respondents also risk further alienation and possible discrimination of already othered groups.

The Gothic lens contributes to the analysis by illuminating how the "reel" is adopted by the professionals within the institutions of authority, becoming a part of the "real" world because the ideas in the "reel" influence the approach and methods that the professionals 
use to prevent violence. The respondents are consequently constructing a violence regime for gender-based violence, where some types of violence are rendered (in)visible, (il)legitimate, and (un)recognized. Similar to regimes of gender, a regime of violence can be defined as a structured set of orders related to the modern state or sites of governmental power, which renders certain forms of violence visible, legitimate and recognized and others invisible, illegitimate and unrecognized (Schinkel 2013; Skott 2020). As such, hegemonic and heteronormative power structures, including orders of gender and ethnicity, shape the current regimes of violence evident in various sites of power, and may also be used as state mediums of governing conduct. The failure to examine what these violence regimes entail runs the risk that the state definitions of violence will be reproduced uncritically (Schinkel 2013). Analyzing and problematizing these regimes of violence is, therefore, highly relevant in order to reexamine the power structures on which these regimes of violence are built and the orders and discourses they (re)produce.

This study has shown that there is a Gothic logic to the narratives of local-level municipal authorities around violence, demonstrating a link between the "reel" and the "real." This has significant implications for understanding the impact of cultural (Gothic) presentations on policy and criminal justice. With the increasing new rise of punitive populism, underpinned by Gothic tropes (Valier 2002), as well as an increasing fascination with gritty "true crime" and mediated stories of violence, all highly influenced by the Gothic imagination (Sothcott 2016), the impact of these "reel" constructions on "real" policies becomes increasingly important and relevant for future research. As this study demonstrates, the narratives of gender-based violence are permeated by the Gothic, which constructs certain groups of offenders as visible and illuminated and others as invisible and obscured. It is in this obscurity, in the shadow of the monster, that future studies should turn their focus. For not all offenders, are as monstrous and as unfamiliar as the wolf.

Funding Open access funding provided by Mid Sweden University.

Open Access This article is licensed under a Creative Commons Attribution 4.0 International License, which permits use, sharing, adaptation, distribution and reproduction in any medium or format, as long as you give appropriate credit to the original author(s) and the source, provide a link to the Creative Commons licence, and indicate if changes were made. The images or other third party material in this article are included in the article's Creative Commons licence, unless indicated otherwise in a credit line to the material. If material is not included in the article's Creative Commons licence and your intended use is not permitted by statutory regulation or exceeds the permitted use, you will need to obtain permission directly from the copyright holder. To view a copy of this licence, visit http://creativecommons.org/licenses/by/4.0/.

\section{References}

Beal, T. K. (2002). Religion and its monsters. New York: Routledge.

Botting, F. (1996). Gothic. New York: Routledge.

Brännström, L., Nyhlén, S., \& Gillander-Gådin, K. (2019). "You are so ugly, you whore"-Girls in rural Sweden discuss and address gendered violence. International Journal of Qualitative Studies in Health \& Well-Being, 15(1), 1-11. https://doi.org/10.1080/17482631.2019.1695308.

Brookman, F., Copes, H., \& Hochstetler, A. (2011). Street codes as formula stories: How inmates recount violence. Journal of Contemporary Ethnography, 40(4), 397-424.

Brothers Grimm. (1812/2014). The original folk and fairy tales of the Brothers Grimm (J. Zipes, Trans.). Princeton NJ: Princeton University Press.

Christie, N. (1986). The ideal victim. In E. A. Fattah (Ed.), From crime policy to victim policy (pp. 17-30). London: Palgrave Macmillan. 
Cook, E. A., \& Walklate, S. (2019). Excavating victim stories: Making sense of agency, suffering and redemption. In J. Fleetwood, L. Presser, S. Sandberg, \& T. Ugelvik (Eds.), The Emerald handbook of narrative criminology (pp. 239-257). Bingley, UK: Emerald Publishing Limited.

Derrida, J. (1978). Of grammatology (G. Chakravorty Spivak, Trans.). Baltimore, MD: Johns Hopkins University Press.

DiBennardo, R. (2018). Ideal victims and monstrous offenders: How the news media represent sexual predators. Socius: Sociological Research for a Dynamic World, 4(1), 1-20.

Erlingsson, G. Ó., \& Wänström, J. (2015). Politik och förvaltning i svenska kommuner. Lund: Studentlitteratur.

Fernandez, M., Niedenthal, S., \& Armenteros, M. (2013). The sense of lighting inside game worlds. Myth and meaning in gameplay and game mechanics. In K. Mitgutsch, S. Huber, J. Wimmer, M. G. Wagner, \& H. Rosenstingl (Eds.), Context matters! Proceedings of the Vienna games conference 2013: Exploring and reframing games and play in context (pp. 57-69). Vienna: New Academic Press.

Fiddler, M. (2013). Playing funny games in the last house on the left: The uncanny and the "home invasion" genre. Crime Media Culture, 9(3), 281-299.

Fleetwood, J. (2016). Narrative habitus: Thinking through structure/agency in the narratives of offenders. Crime Media Culture, 12(2), 173-192.

Frank, A. W. (2010). Letting stories breathe. Chicago, IL: The University of Chicago Press.

Fredriksson, T. (2019). Abject (m)othering: A narratological study of the prison as an abject and uncanny institution. Critical Criminology: An International Journal, 27(2), 261-272. https://doi.org/10.1007/ s10612-018-9412-0.

Freud, S. (1919/2001). The complete psychological works of Sigmund Freud, Vol. 17 (1917-1919) (J. Strachey, Ed.). London: Vintage Classics.

Greer, C. (2003). Media representations of dangerousness. Criminal Justice Matters, 51(1), 4-5.

Greer, C. (2012). Sex crime and the media: Sex offending and the press in a divided society. Cullompton: Willan.

Haslam, F. (2007). Gothic: A rhetorical hermeneutics approach. The Irish Journal of Gothic and Horror Stories, 2(1), 3-26.

Higgins, E., \& Swartz, K. (2018). The knowing of monstrosities: Necropower, spectacular punishment and denial. Critical Criminology: An International Journal, 26(1), 91-106. https://doi.org/10.1007/s1061 2-017-9382-7.

Hourigan, K. L. (2019). Narrative victimology: Speaker, audience, timing. In J. Fleetwood, L. Presser, S. Sandberg, \& T. Ugelvik (Eds.), The Emerald handbook of narrative criminology (pp. 279-300). Bingley, UK: Emerald Publishing Limited.

Hurley, K. (2007). Abject and grotesque. In C. Spooner \& E. McEvoy (Eds.), The Routledge companion to Gothic (pp. 137-146). London: Routledge.

Ievins, A. (2019). Finding victims in the narratives of men imprisoned for sex offences. In J. Fleetwood, L. Presser, S. Sandberg, \& T. Ugelvik (Eds.), The Emerald handbook of narrative criminology (pp. 1-21). Bingley, UK: Emerald Publishing Limited.

Ingebretsen, E. J. (2001). At stake: Monsters and the rhetoric of fear in public culture. Chicago, IL: Chicago University Press.

Jewkes, Y. (2015). Media and crime. Thousand Oaks, CA: SAGE.

Kohm, S., \& Greenhill, P. (2013). This is the north, where we do what we want": Popular green criminology and "little red riding hood films. In N. South \& A. Brisman (Eds.), Routledge international handbook of green criminology (pp. 365-378). Abingdon, Oxon, UK: Routledge.

Kristeva, J. (1982). Powers of horror, an essay on abjection. New York: Colombia University Press.

Lancaster, R. (2011). Sex panic and the punitive state. Berkeley, CA: University of California Press.

Leon, C. S. (2011). Sex fiends, perverts, and pedophiles: Understanding sex crime policy in America. New York: NYU Press.

Linnemann, T. (2015). Capote's ghosts: Violence, media and the specter of suspicion. The British Journal of Criminology, 55(3), 514-533.

Linnemann, T. (2016). Meth wars: Police, media, power. New York: New York University Press.

Livholts, M. (2007). Vanlig som vatten: manlighet och normalitet i mediernas berättelser om våldtäkt (Usual as water: Masculinity and normality in media narratives on rape). Lund: Gleerups utbildningsförlag.

Markey, A. (2014). The Gothicization of Irish Folklore. In C. Morin \& N. Gillespie (Eds.), Irish Gothics: Genres, forms, modes, and traditions 1760-1890 (pp. 94-112). London: Palgrave McMillan.

Maruna, S., \& Copes, H. (2005). What have we learned from five decades of neutralization research? Crime and Justice: A Review of Research, 32, 221-320.

McClanahan, B., \& Linnemann, T. (2018). Darkness on the edge of town: Visual criminology and the "black sites" of the rural. Deviant Behavior, 39(4), 512-524. 
McEvoy, C. (2007). Gothic Traditions. In C. Spooner \& E. McEvoy (Eds.), The Routledge Companion to Gothic (pp. 7-10). New York: Routledge.

McGoey, L. (2012). The logic of strategic ignorance. The British Journal of Sociology, 63(3), 553-576.

Nagel, J. (2003). Race, ethnicity, and sexuality: Intimate intersections, forbidden frontiers. New York: Oxford University Press.

Niedenthal, S. (2009). Patterns of obscurity: Gothic setting and light in Resident Evil 4 and Silent Hill 2. In B. Perron (Ed.), Horror video games: Essays on the fusion of fear and play (pp. 168-188). London: McFarland \& Company Inc.

Nyhlén, S., \& Giritli Nygren, K. (2019). "It's about gender equality and all that stuff” enacting gender based violence policy into everyday preventive work in rural Sweden. The Journal of Gender-Based Violence, 3(3), 1-17.

Pemberton, A., Mulder, E., \& Aarten, P. G. (2018). Stories of injustice: Towards a narrative victimology. European Journal of Criminology., 16(4), 391-412. https://doi.org/10.1177/1477370818770843.

Picart, C. J. K., \& Greek, C. (2007). Introduction: Toward a Gothic criminology. In C. J. K. Picart \& C. Greek (Eds.), Monsters in and among us: Toward a Gothic criminology (pp. 11-44). Madison, NJ: Fairleigh Dickinson University Press.

Rafter, N., \& Ystehede, P. (2010). Here be dragons: Lombroso, the Gothic and social control. In M. Deflem (Ed.), Popular culture, crime and social control (Sociology of Crime, Law and Deviance, Vol. 14) (pp. 263-284). Bingley, UK: Emerald Group Publishing Limited.

Rogers, M. (2019). Challenging cisgenderism through trans people's narratives of domestic violence and abuse. Sexualities, 22(5-6), 803-820.

Sandberg, S., Tutenges, S., \& Copes, H. (2015). Stories of violence: A narrative criminological study of ambiguity. The British Journal of Criminology, 55(6), 1168-1186.

Schinkel, W. (2013). Regimes of violence and the trias violantae. European Journal of Social Theory, 16(3), $310-325$.

Shelley, M. (1818/2013). Frankenstein: Or, the modern Prometheus. Richmond, UK: Alma Classics Ltd.

Skott, S. (2020). Maskulinitet och våld i förändring: Våldsregimer och privatisering av våld $i$ Skottland [Masculinity and violence in flux: Regimes of violence and the privatization of violence in Scotland]. Sundsvall: Forum for Gender Studies, Mid Sweden University.

Sothcott, K. (2016). Late modern ambiguity and Gothic narratives of justice. Critical Criminology: An International Journal, 24(3), 431-444. https://doi.org/10.1007/s10612-015-9287-2.

SOU [Statens Offentliga Utredningar]. (2015). Nationell Strategi mot mäns våld mot kvinnor och hedersrelaterat våld och förtryck (SOU 2015:55) (National strategy against men's violence against women and honour-based violence and oppression). Stockholm: Regeringskansliet.

South, N. (2017). Monstrous nature: A meeting of Gothic, green and cultural criminologies. In M. Brown \& E. Carrabine (Eds.), Routledge international handbook of visual criminology (pp. 553-556). London: Routledge.

Spittle, S. (2011). "Did this game scare you? Because it sure as hell scared me!" F.E.A.R., the Abject and the Uncanny. Game and Culture, 6(4), 312-326.

Spooner, C. (2007). Contemporary Gothic. London: Reaktion Books.

Spooner, C., \& McEvoy, E. (Eds.). (2007). Introduction. In The Routledge Companion to Gothic (pp. 1-5). New York: Routledge.

Surette, R. (2007). Gothic criminology and criminal justice policy. In C. J. Picart \& C. Greek (Eds.), Monsters in and among us: Towards a Gothic criminology (pp. 199-226). Madison, NJ: Fairleigh Dickinson University Press.

Sykes, G. M., \& Matza, D. (1957). Techniques of neutralization: A theory of delinquency. American Sociological Review, 22(6), 664-670.

Valier, C. (2002). Punishment, border crossings and the powers of horror. Theoretical Criminology, 6(3), 319-337.

Walklate, S., Maher, J., McCulloch, J., Fitz-Gibbon, K., \& Beavis, K. (2019). Victim stories and victim policy: Is there a case for a narrative victimology? Crime Media Culture, 15(2), 199-215. https://doi. org/10.1177/1741659018760105.

Walpole, H. (1764/2014). The Castle of Otranto. Oxford: Oxford University Press.

Young, J. (2007). The vertigo of late modernity. London: Sage Publishing.

Publisher's Note Springer Nature remains neutral with regard to jurisdictional claims in published maps and institutional affiliations. 